\title{
Knowledge processes in virtual teams: consolidating the evidence
}

\begin{abstract}
This article takes stock of the current state of research on knowledge processes in virtual teams and consolidates the extent research findings. Virtual teams, on the one hand, constitute important organizational entities that facilitate the integration of diverse and distributed knowledge resources. On the other hand, collaborating in a virtual environment creates particular challenges for the knowledge processes. The article seeks to consolidate the diverse evidence on knowledge processes in virtual teams with a specific focus on identifying the factors that influence the effectiveness of these knowledge processes. The article draws on the four basic knowledge processes outlined by Alavi and Leidner (2001) (i.e., creation, transferring, storage/retrieval and application) to frame the investigation and discuss the extent research. The consolidation of the existing research findings allows us to recognize the gaps in the understanding of knowledge processes in virtual teams and identify the important avenues for future research.
\end{abstract}




\section{INTRODUCTION}

The globalization of business competition and a growing need for customer responsiveness in the past few decades have caused an increasing number of firms to undergo dramatic organizational changes (Miles \& Snow, 1992). Organizations transform to networks by flattening organizational structure and establishing inter-organizational links (Davidow \& Malone, 1992). This change has promoted contemporary firms to coordinate activities that span geographical and organizational boundaries (Townsend et al., 1998). It has also increased the need for utilizing decentralized, specialized knowledge and expertise (Alavi \& Tiwana, 2002; Boutellier, 1998; Penrose, 1959). Virtual teams have emerged to allow organizations to overcome these geographical boundaries and to address the emerging knowledge needs (Powell et al., 2004; Workman, 2007).

Virtual teams constitute essential structures in today's organizations (Siebdrat et al., 2009). An internal virtual workforce survey of twelve hundred employees in Intel Corporation reveals that approximately 70 percent of the Intel workforce collaborates with people in different time zones without meeting face to face (Intel Corporation, 2004). Accenture, an international IT systems consulting firm, rests its viability on the performance of "customerintimate" project teams coordinated among dispersed sites (Accenture., 2005 ). Virtual teams form an essential part of today's organizations with important implications for teamwork and collaboration.

A crucial aspect of virtual teams is the knowledge process among the team members. In fact, the main driver for building virtual teams is the prospect of integrating the dispersed knowledge and expertise of the team members (Alavi \& Tiwana, 2002; Boutellier, 1998). However, while virtual teams are established to support knowledge integration it has been recognized that the virtual collaboration environment inhibits the team's knowledge 
processes. The geographic dispersion and the reliance on information technologies hinder team members to create, transfer, store and apply knowledge (Alavi \& Tiwana, 2002; Cramton, 2001; Griffith et al., 2003). Studies in innovation management (Ahuja, 2000) and organizational learning (Walsh, 1995) highlight how the distributed nature of cognition and the diversity of knowledge in team settings creates challenges for team learning and knowledge processes. These challenges become even more pronounced when the interaction among teams are virtual (Alavi \& Tiwana, 2002).

Virtual teams are in a "catch-22" situation: the opportunities of integrating dispersed knowledge promotes the emergence of virtual teams; at the same time virtual teams are arguably less capable of identifying and leveraging the collective knowledge of their members than traditional teams are. Recognizing this paradox is highly important for virtual team members as effective knowledge exchange and utilization is not achieved until the team has identified ways for managing the diverse knowledge processes.

Although a range of studies on knowledge processes in virtual teams has been undertaken, the emerging body of research lacks a common basis that puts the different contributions into perspective with each other. Contributions originate from domains as diverse as organizational behavior, information science or innovation studies with each study adopting individual perspectives, models and variables. The diversity of contributions makes it increasingly difficult to establish what is already known about the knowledge processes of virtual teams and to isolate the remaining research questions. In order to advance research on knowledge processes in virtual teams and to support further targeted work in the area, we have set out to address the question of: What factors influence the effectiveness of knowledge processes in virtual teams? We review and consolidate the extant literature to identify factors that influence knowledge process effectiveness, which is defined as the extent to which 
knowledge processes support a team in fulfilling its objective (following the established notion of team process effectiveness (Dean \& Sharfman, 1996). By developing an overarching framework that integrates the extent research our work has the potential to rapidly fill the gaps in the understanding of knowledge process issues in virtual teams and help move forward research and practice in the field.

The paper is organized as follows. First, we present the overarching framework to structure the knowledge processes in the extant empirical literature. Second, we organize previously published papers in terms of the framework and review the factors influencing the knowledge processes in virtual teams. Finally avenues for future research are discussed.

\section{RESEARCH ON KNOWLEDGE PROCESSES IN VIRTUAL TEAMS}

The significance of knowledge processes for virtual teams is characterized by three core arguments. First, knowledge processes of virtual teams have important implications for organizational and individual learning. The organizational learning literature has stressed that the team is the fundamental learning unit in an organization (Edmondson, 1999; Senge, 1990) and a major mechanism for integrating its knowledge resources (Grant, 1996). Teams are also important for individual learning in that individual cognition and behavior is shaped by the social context in which people work (Edmondson, 2002; Hackman, 1992). This perspective is also highlighted in studies on the group-to-individual transfer of learning (Olivera \& Straus, 2004).

Second, virtual teams have assumed an increasingly important role in leveraging and integrating knowledge across geographically dispersed organizations. Virtual teams play a critical role in productive work (such as innovation, Leonard \& Sensiper, 1998; Malhotra et al., 2001), in reacting to a shortage of expertise (caused by today's trends toward downsizing, 
globalization), and in addressing employees' preference for increased mobility and flexibility (Markus et al., 2000; Townsend et al., 1998).

Third, a goal of virtual teamwork should be to accomplish tasks more effectively by making better use of available knowledge. Consequently, research examining virtual teamwork must view learning and knowledge as a means, rather than a goal in itself, as shown in the distance-learning literature (e.g. Alavi \& Leidner, 2001). Given the significance of knowledge related issues in virtual teams, the current body of research on this topic should be preserved and future research directions need to be identified.

While other literature reviews on virtual teams have been carried out (Hertel et al., 2005; Martins et al., 2004; Pinsonneault \& Caya, 2005; Powell et al., 2004; Saunders, 2000), and publications have conceptualized the implications of virtual team environments on knowledge work (Assudani, 2009; Bosch-Sijtsema et al., 2009) no major review analyzing and integrating the diverse empirical studies on knowledge processes within virtual teams has been published to date. As the enabling of knowledge processes is one of the core motivations of forming virtual teams we address this gap by reviewing the existing research in the context of virtual teams.

\section{A FRAMEWORK OF KNOWLEDGE PROCESSES}

Our review is built on the basis of a framework of four knowledge processes identified by Alavi and Leidner (2001). According to this framework, organizations represent knowledge systems consisting of four sets of socially enacted knowledge processes: (1) creation, (2) storage/retrieval, (3) transfer and (4) application. The focus on social collectives as knowledge systems is grounded in the sociology of knowledge (Berger \& Luckmann, 1967; Gurvitch et al., 1971; Holzner \& Marx, 1979) which considers groups and its members' interactions as the critical unit for knowledge process analysis. 
Knowledge creation describes changes in an individual's mental models or knowledge representations. According to this definition, learning involves the acquisition of knowledge and changes in knowledge structures rather than a behavior per se (Grant, 1996; Greeno, 1974; Kwok et al., 2002). Thus, knowledge creation is essentially a process of acquiring knowledge in order to create new knowledge. Alavi and Leidner's (2001) notion has some limitations, as it considers knowledge creation as a homogenous process whereas other scholars have elaborated on diverse facets within the knowledge creation process (Argyris \& Schon, 1978; Kolb \& Fry, 1975). Knowledge transfer refers to the process of conveying knowledge to locations or individuals where it is needed and can be used (Alavi \& Leidner, 2001) often with the help of repositories or other technology based systems (Wu et al., 2010). Knowledge storage/retrieval refers to the process of collecting knowledge and making it accessible, commonly requiring steps of encoding and decoding the knowledge resource (Gammelgaard, 2010). Finally, knowledge application in the form of task teams refers to the application of knowledge for problem solving (Grant, 1996).

Our choice of Alavi and Leidner's (2001) framework to structure our review of knowledge processes in virtual teams is justified by its parsimony and wide-spread application in the IS domain. Although other frameworks are available (see Rubenstein-Montano, 2001), Alavi and Leidner's (2001) focus on four major knowledge processes provides a level of granularity that allows for subsequent pattern analysis (Peachy et al., 2005). It is widely used to conceptualize comprehensive knowledge process investigations (e.g. Palanisamy, 2007) or to define individual processes (e.g. Choi et al., 2010; Lee \& Choi, 2003). Focusing on Alavi and Leidner's (2001) framework to structure our assessment of the literature on knowledge processes in virtual teams increases the utility of our investigation and allows us to add to the cumulative research on knowledge processes (Guo \& Sheffield, 2008; Keen, 1980). 


\section{METHODOLOGY FOR LITERATURE SELECTION}

Three means were used to identify relevant articles concerning knowledge processes in virtual teams. First, and consistent with prior formal literature reviews published (Martins et al., 2004; Pinsonneault \& Caya, 2005; Powell et al., 2004), a computer search using ABI/INFORM was conducted, and search results were manually screened to eliminate irrelevant hits. ABI/INFORM is widely regarded as the most comprehensive online portal for academic papers, and has been used for literature reviews in existing studies (Powell et al., 2004). We included as many relevant studies as possible by relaxing search criteria to obtain a wider range of articles related to knowledge processes in virtual teams. More precisely, we used "virtual/dispersed/non-collocated/computer-mediated/IT-mediated" as keywords to search through abstracts. In the same logic, we used "team/group" to capture the notion of team. While acknowledging that teams and groups are different in terms of task interdependence, the two terms are often used interchangeably in traditional and virtual team research (Cohen \& Bailey, 1997; Langfred, 1998). To capture knowledge issues in virtual teams, "learning/knowledge/innovation/problem solving" were used as keywords to search in article abstracts for hints on knowledge processes. Among these keywords, innovation in virtual teams commonly represents knowledge acquisition and knowledge application processes, whereas problem-solving may capture knowledge application processes (Alavi \& Tiwana, 2002). We focus on keywords within abstracts only because we assume that an article does not concern with knowledge issues in virtual teams if it doesn't have the defined keywords in its abstract, as the abstract summarizes the major research questions, methods and findings.

Another major source are literature review articles, such as Powell et al (2004), Martins et al. (2004) and Hertel et al (2005) and their extensive references. We examined the reviews and identified 11 papers dealing with issues of knowledge processes in virtual teams. Thirdly, we 
referred to resources on virtual teams located on the ISWORLD website, and identified 4 papers concerning knowledge processes in virtual teams.

All articles identified were read to determine if the issue and the unit of analysis met our search criteria (i.e., knowledge transfer, knowledge application, knowledge creation, and knowledge storage/retrieval in geographically dispersed teams). It was also confirmed that the described knowledge processes met the widely accepted definitions originally provided by Alavi and Leidner (2001). 33 papers were ultimately identified as meeting the criteria for inclusion and were analyzed in the literature review. All journal papers identified are published in SCOPUS-listed journal outlets with more than $80 \%$ of the papers ranked in the first two quality quartiles in their respective subject categories (based on the SNJ index, González-Pereira et al., 2010). These papers are categorized in detail in Appendix 1 (their references form part of the list of references of this paper).

\section{LITERATURE ANALYSIS ON KNOWLEDGE PROCESSES IN VIRTUAL TEAMS}

In the current section, we first explore which knowledge processes have been studied by categorizing the 33 papers according to Alavi and Leidner's (2001) framework. We manually screened all papers to examine the team-based knowledge processes that each paper focuses on. Following our research question we identified the major issues that impact on these knowledge processes and categorize them according to the input-process-output model. The input-process-output model is the dominant framework used in studies of teams and provides a sound basis for organizing and integrating the literature on Virtual Teams (VT) (Martins et al., 2004; Pinsonneault \& Caya, 2005; Powell et al., 2004). We identify two broad categories of factors impacting on the knowledge processes within teams: input factors and process factors. Input factors refer to a priori features that a team has upon its formation. Process 
factors refer to emerging aspects that influence the practice among team members. The review has shown that virtual team research has considered both input and process factors with their impact on the team's knowledge processes.

The specific range of input and process factors encountered in the analysis focus on the team's information technology, member configuration, socio-cognitive properties and specific interventions. Information technology related factors cover aspects of technology choice but also aspects of technology use. Member configuration factors are largely conceptualized as input factors and include aspects such as team dispersion, virtualness or the diversity of experiences present among team members. In contrast, factors related to the team's socio-cognitive properties, such as trust or transactive memory, were largely considered as process factors (emerging within the team). The range of specific interventions considered with their impact on the team's knowledge processes include factors like training or leadership initiatives.

The literature review has revealed that all four knowledge processes (creation, storage, transfer, application) have been investigated in the existing virtual team literature. The most studied KM process is knowledge transfer (16 articles), while the least studied is knowledge storage/retrieving (2 articles). Knowledge creation (10 articles) and knowledge application (10 articles) in virtual teams have been moderately studied. Most of the papers (i.e., 24 papers) focus on only one knowledge process while six cover two knowledge processes (Haas, 2006; Majchrzak, Rice, King, et al., 2000; Majchrzak, Rice, Malhotra, et al., 2000; Malhotra \& Majchrzak, 2004; Malhotra et al., 2001; Robert et al., 2008), and one covers three KM processes (Paul, 2006). Table 1 presents a high-level summary of the major input and process factors identified as impacting on the knowledge processes of virtual team, as well as the theories and methods that appear in each category. The listing of the theories and 
methods indicate the predominant research perspectives and data collection methods employed so as to obtain a more comprehensive understanding of the specific range and nature of studies investigating each particular knowledge process. The next section focuses on each knowledge process in detail and discusses how the knowledge processes are impacted by the different input and process factors identified.

Table 1: Summary of Articles on knowledge management processes in Virtual Teams

\begin{tabular}{|c|c|c|c|c|}
\hline $\begin{array}{l}\text { Knowledge } \\
\text { processes }\end{array}$ & Articles & $\begin{array}{l}\text { Factors influencing } \\
\text { effectiveness (\#) }\end{array}$ & Theories (\#) & Methods (\#) \\
\hline $\begin{array}{l}\text { Knowledge } \\
\text { Creation } \\
\text { (10 articles) }\end{array}$ & $\begin{array}{l}\text { (Alavi et al., 2002) } \\
\text { (Ocker \& Yaverbaum, } \\
\text { 1999) } \\
\text { (Capece \& Costa, 2009) } \\
\text { (Robey et al., 2000) } \\
\text { (Vogel et al., 2001) } \\
\text { (Alavi, 1994) } \\
\text { (Qureshi \& Vogel, } \\
\text { 2001) } \\
\text { (Haas, 2006) } \\
\text { (Majchrzak et al., 2005) } \\
\text { (Paul, 2006) } \\
\text { (Vaccaro et al., 2009) }\end{array}$ & $\begin{array}{l}\text { Input: } \\
\text { IT use (3); } \\
\text { Choice of IT tools (1); } \\
\text { Learning interveners (1); } \\
\text { Diversity of member } \\
\text { experience (1); Structural } \\
\text { configuration (1) } \\
\text { Process: } \\
\text { Situated learning (1); } \\
\text { Collaborative know-how } \\
\text { development (1) }\end{array}$ & $\begin{array}{l}\text { - Technology-mediated } \\
\text { learning (1); } \\
\text { - Computer-mediated } \\
\text { communication (1); } \\
\text { - Situated learning (1); } \\
\text { - Socio-cultural } \\
\text { learning (1); } \\
\text { - Social learning theory } \\
\text { (1) } \\
\text { - Structuration theory } \\
(1) \\
\text { - Cognitive-affective } \\
\text { model (1) } \\
\text { - Knowledge creation } \\
\text { model (SECI) (1) }\end{array}$ & $\begin{array}{l}\text {-Qualitative } \\
\text { interview (1); } \\
\text { - Case study (3); } \\
\text { - Experiment } \\
\text { (2); } \\
\text {-Survey (2) } \\
\text { (2 conceptual } \\
\text { papers) } \\
\text {-Social network } \\
\text { analysis (1) }\end{array}$ \\
\hline $\begin{array}{l}\text { Knowledge } \\
\text { Transfer } \\
\text { (12 articles) }\end{array}$ & $\begin{array}{l}\text { (Griffith et al., 2003) } \\
\text { (Behrend \& Erwee, } \\
\text { 2009) } \\
\text { (Cramton, 2001) } \\
\text { (Griffith \& Neale, } \\
\text { 2001) } \\
\text { (Yoo, 2001) } \\
\text { (Sole \& Applegate, } \\
\text { 2000) } \\
\text { (Majchrzak, Rice, King, } \\
\text { et al., 2000) } \\
\text { (Majchrzak, Rice, } \\
\text { Malhotra, et al., 2000) } \\
\text { (Malhotra et al., 2001) } \\
\text { (Malhotra \& } \\
\text { Majchrzak, 2004) } \\
\text { (Sole \& Edmondson, } \\
\text { 2002) } \\
\text { (Baba et al., 2004) } \\
\text { (Paul, 2006) } \\
\text { (Chang, 2008) } \\
\text { (Ratcheva, 2009) } \\
\text { (Staples \& Webster, } \\
\text { 2008) } \\
\text { (Robert et al., 2008), } \\
\text { (Kim \& Jarvenpaa, } \\
\text { 2008) }\end{array}$ & $\begin{array}{l}\text { Input: training, team } \\
\text { dispersion virtualness, IT } \\
\text { use, team structure (6); } \\
\text { Task demand (1) } \\
\text { trust, virtualness, task } \\
\text { characteristics (1) } \\
\text { Social capital (2) } \\
\text { Process: } \\
\text { Shared understanding, } \\
\text { transactive memory, } \\
\text { mutual understanding, } \\
\text { situated knowledge, } \\
\text { technology use norms, } \\
\text { coherence (6); } \\
\text { Cognitive Convergence } \\
\text { (1) } \\
\text { embeddedness, knowledge } \\
\text { sharing obligations (1) } \\
\text { Boundary spanning (1) } \\
\text { Output: team effectiveness } \\
\text { (1) } \\
\text { Team decision quality (1) }\end{array}$ & $\begin{array}{l}\text { - Communication } \\
\text { theory (5) } \\
\text { - Transactive memory } \\
\text { (1) } \\
\text { - Social cognitive } \\
\text { literature (1) } \\
\text { - Theory of shared } \\
\text { meaning (1) } \\
\text { - Adaptive } \\
\text { Structuration Theory } \\
\text { (1) } \\
\text { - Situated learning (1), } \\
\text { Psychological contract } \\
\text { theory (1), } \\
\text { Social exchange theory } \\
\text { (1), } \\
\text { Social capital (1) }\end{array}$ & $\begin{array}{l}\text { - Document } \\
\text { analysis (1) } \\
\text { - Experiment } \\
(2) \\
\text { - Survey (3) } \\
\text { - Case study (8) } \\
\text { (3 conceptual } \\
\text { papers) }\end{array}$ \\
\hline
\end{tabular}




\begin{tabular}{|c|c|c|c|c|}
\hline $\begin{array}{l}\text { Knowledge } \\
\text { Storage/ } \\
\text { Retrieving } \\
\text { (2 articles) }\end{array}$ & $\begin{array}{l}\text { (Malhotra et al., 2001) } \\
\text { (Majchrzak, Rice, } \\
\text { Malhotra, et al., 2000) }\end{array}$ & $\begin{array}{l}\text { Input: The role of } \\
\text { knowledge manager (1); } \\
\text { Output: Usefulness of } \\
\text { knowledge repository (1) }\end{array}$ & $\begin{array}{l}\text { - Communication } \\
\text { literature (1) (used only } \\
\text { to develop opposing } \\
\text { hypotheses) }\end{array}$ & - Case study (2) \\
\hline $\begin{array}{l}\text { Knowledge } \\
\text { Application } \\
\text { (9 articles) }\end{array}$ & $\begin{array}{l}\text { (Majchrzak, Rice, } \\
\text { Malhotra, et al., 2000) } \\
\text { (Alavi \& Tiwana, 2002) } \\
\text { (Boutellier, 1998) } \\
\text { (Kruempel, 2000) } \\
\text { (Archer, 1990) } \\
\text { (Malhotra \& } \\
\text { Majchrzak, 2004) } \\
\text { (Haas, 2006) } \\
\text { (Gibson \& Gibbs, } \\
\text { 2006) } \\
\text { (Paul, 2006) } \\
\text { (Robert et al., 2008) }\end{array}$ & $\begin{array}{l}\text { Input: } \\
\text { Comparison b/w VT and } \\
\text { TT (3); } \\
\text { Leader (1); } \\
\text { Use of IT (1); } \\
\text { Diversity of member } \\
\text { international experience } \\
\text { (1); } \\
\text { Virtualness (1) } \\
\text { Social capital } \\
\text { Process: } \\
\text { Transactive memory (1) } \\
\text { Mutual understanding (1) } \\
\text { Structural change in } \\
\text { process (2) } \\
\text { Output: Team decision } \\
\text { quality }\end{array}$ & $\begin{array}{l}\text { - Structuration theory } \\
\text { (5) } \\
\text { - Communication } \\
\text { theory (2) } \\
\text { - Social information } \\
\text { processing (1) } \\
\text { Social capital (1) }\end{array}$ & $\begin{array}{l}\text { - Experiment (4) } \\
\text { - Case study (2) }\end{array}$ \\
\hline
\end{tabular}

\#: Number of papers

\section{Knowledge creation}

Knowledge creation is the process of learning that changes team members' mental models or knowledge representations to produce new knowledge. Research to date has touched upon the effect of using information technology on team knowledge creation (Alavi, 1994; Alavi et al., 2002; Ocker \& Yaverbaum, 1999; Vaccaro et al., 2009) and collaborative know-how development (Majchrzak et al., 2005), situated learning in a virtual environment (Robey et al., 2000), the factors that enable knowledge creation (Capece \& Costa, 2009; Vogel et al., 2001), and the benefits of acquiring knowledge in virtual teams (Saunders, 2000).

Input factors: First, the existing studies have examined how team dispersion facilitates the creation effectiveness by comparing dispersed teams and face-to-face teams. The findings suggest that computer-mediated learning can be as effective as face-to-face learning (Ocker \& Yaverbaum, 1999). Second, early studies encountered mixed evidence concerning the effect of using advanced information systems on knowledge creation. On the one hand, it is 
found that the learning outcome of virtual teams supported by advanced Group Systems is superior to non-supported virtual teams (Alavi, 1994). It is suggested that advanced information structuring and facilitated exposure to diverse perspectives provides superior basis for mental model development On the other hand, it was found that virtual teams using email perform better than advanced IT-supported teams in a learning environment (Alavi et al., 2002). The reason might be that cognitive load required for mastering advanced information systems is much higher than that for email; therefore members' remaining cognitive resources to learn are reduced in virtual teams with advanced IT (Alavi et al., 2002). Third, recent literature looked at how virtual team composition (e.g., locals versus cosmopolitans) (Haas, 2006) and structural configuration (Capece \& Costa, 2009) influences a team's knowledge creation process which is explained by the different communication structures that emerge among team members.

Process factors: Vogel et al (2001) identify nine enabling process factors analyzing the cases of seven virtual teams (e.g., assisted learning, cognitive apprenticeship). Communities of practice and situated learning are regarded as important means to facilitate knowledge creation by embedding good practices (Robey et al., 2000). Majchrzak et al. (2005) found collaboration know-how development to be an instrumental process that facilitates knowledge creation as it contributes to idea communication and integration with other members. Vacarro et al (2009) were able to show that Nonaka's prominent SECI model of knowledge creation (socialization, externalization, internalization, combination) is a valid model to depict the knowledge creation process in virtual teams.

\section{Knowledge transfer}

Knowledge transfer refers to the transmitting of knowledge to locations where it is needed and can be used (Alavi \& Leidner, 2001). To capture the knowledge transfer process the 
literature has focused on the communication process between team members, the extent and quality of the exchanges and the factors that impact these.

Input factors: Different factors have been identified to influence communication processes within virtual teams. Virtualness, defined as time that team members spend apart on tasks, is suggested to negatively influence collective knowledge and shared understanding (Griffith et al., 2003), and to negatively influence development of a shared cognitive structure (Griffith \& Neale, 2001). The negative influence is explained by the diminishing level of integration and loyalty between employee and organization in highly virtual teams. Training that targets the development of communication and media competencies is suggested to be useful in enhancing coherence within virtual teams (Cornelius \& Boos, 2003). Staples et al (2008) have pointed out that hybrid teams (partly collocated) risk the creation of in-groups which create an even higher impediment to knowledge sharing than an overall high degree of virtualness. For highly innovative virtual teams that are innovating in both process and team tasks, keeping a malleable structure that can evolve over time is important for completion of the innovative task (Majchrzak, Rice, Malhotra, et al., 2000; Malhotra et al., 2001).

Another structural input factor is the use of information technologies. The use of collaborative technology has been suggested to moderate the effect between team virtualness and shared understanding (Griffith et al., 2003) as such technology contributes to the development of a shared cognitive structure. Majchrzak et al (2000) in turn suggest that such shared cognitive structures allows teams to use information technology effectively even for highly complex knowledge transfers.. However, not all types of information technologies are suitable for knowledge transfer: paradoxically, overly rich media such as video conferencing facilities are not perceived as effective in transferring explicit knowledge as too may communication cues distract from the content (Paul, 2006). 
Process factors: The existing literature has achieved consensus that an effective communication process within virtual teams is essential to knowledge transfer and subsequently to team performance (Cornelius \& Boos, 2003; Cramton, 2001; Griffith \& Neale, 2001; Griffith et al., 2003; Sole \& Applegate, 2000). A number of factors facilitating effective communication have been identified, including shared understanding/mutual knowledge (Cornelius \& Boos, 2003; Cramton, 2001; Griffith \& Neale, 2001; Griffith et al., 2003), collective knowledge/collective mind (Griffith et al., 2003; Yoo, 2001), transactive memory (Griffith \& Neale, 2001; Griffith et al., 2003; Yoo, 2001), psychological contracts (Chang, 2008), trust (Staples \& Webster, 2008), conversational coherence (Cornelius \& Boos, 2003) and technology use norms (Sole \& Applegate, 2000). Shared understanding, mutual knowledge and mutual understanding all refer to a similar notion-knowledge that the communicating parties have in common (Krauss \& Fussel, 1990), or more broadly as “common ground" (Clark \& Carlson, 1982), which are similar to episodic memory in Alavi and Leidner's (2001) framework. Research has suggested that this kind of tacit team-level knowledge is essential to team performance, such as satisfaction (Cornelius \& Boos, 2003), viability and decision making quality (Cramton, 2001) as it facilitates the effective communication among virtual team members.

Collective knowledge (or collective mind) refers to explicit knowledge that has been internalized by the team members, such as teamwork procedures (Griffith et al., 2003). It is different from shared understanding in the sense that shared understanding is more implicit (Griffith et al., 2003).. Technology use norms can be considered a particular instance of collective knowledge (Sole \& Applegate, 2000), referring to shared knowledge of using a particular technology in the team. By facilitating the interaction among team members technology use norms positively influence knowledge sharing practice and subsequently influence team performance (Sole \& Applegate, 2000). 
Transactive memory is a shared system for encoding, storing, and retrieving knowledge available to the group (Griffith et al., 2003). It captures the team members' meta-knowledge about who knows what in the team (Yoo, 2001). Transactive memory have been suggested to moderate the relationship between communication volume and team performance (Yoo, 2001) and influences a teams' utilization of potential knowledge (Griffith et al., 2003) as a shared knowledge base allows team members ready access to particular expertise.

While the above factors have been shown to impact the team members' ability to transfer knowledge among each other there is little consideration of the fact that knowledge sharing is mostly a voluntary and discretionary activity. Although team members are able to transfer knowledge they can decide not to. Hence, the level of trust (Staples \& Webster, 2008) and the development of mutual obligations (psychological contracts) (Chang, 2008) among virtual team members impact on the knowledge sharing activity among members of a virtual team.

\section{Knowledge storage and retrieving}

Knowledge storage and retrieval largely refers to the practice of codifying knowledge in technology-based systems. While the appropriate knowledge management systems are widely distributed and available to different organizational members (Maier, 2007), our review found only two studies that have specifically looked at knowledge storage and retrieval in virtual teams. One study has found that codified knowledge saved in the knowledge repository is unlikely to be appropriately referenced for later search and retrieval (Majchrzak, Rice, Malhotra, et al., 2000). Storing too much knowledge items within team's electronic knowledge repository can also make the knowledge retrieval difficult due to information overload (Malhotra et al., 2001). To avoid such problem, virtual team members and managers can rely on norms for knowledge storage and codification, thereby allowing for valuable 
information to be archived, and for more efficient usage of embedded search tools (Malhotra et al., 2001).

\section{Knowledge application}

Research to date on knowledge application has looked at structural factors and communication factors that influence team knowledge application in the form of problem solving. The structural factors include leadership effect (Kruempel, 2000), use of IT (Archer, 1990; Boutellier, 1998; Chidambaram \& Jones, 1993; Sharda et al., 1988) and team structure (Clear \& Daniels, 2000; Majchrzak, Rice, Malhotra, et al., 2000).

Input factors: Krumpel (2000) suggests that virtual teams with an effective leader are more capable of applying knowledge in a way that helps them solve organizational problems since ownership and responsibility are clearly allocated. Concerning computer mediation, Boutellier (1998) suggests that intensive use of information technology enables virtual R\&D teams to work more efficiently and effectively. Majchrzak et al (2000) suggest that a malleable structure for highly innovative teams is important for successful completion of innovative tasks. Not surprisingly, research has also revealed that teams with high degree of virtualness (e.g., geographical dispersion, temporal difference) may encounter obstacles in applying knowledge for innovation which is linked to the difficulties of establishing a safe communication environments in a virtual context (Gibson \& Gibbs, 2006). Also, the nature of the task has an influence on the effectiveness of knowledge application and integration. If a task is perceived as intellectually challenging and is highly contextualized, knowledge integration among team members is most effective (Paul, 2006).

Process factors: Alavi et al (2002) suggest that transactive memory, mutual understanding, contextual knowledge and flexibility of organizational ties are all important for knowledge application within virtual teams, and knowledge management systems (KMS) should be 
designed to address these factors. An environment in which communication is characterized by openness, trust, support, respect, and risk taking, is found to be an important factor moderating the effectiveness of knowledge application for innovation (Gibson \& Gibbs, 2006). The development of social capital contributes to the team members use of knowledge of each other (Robert et al., 2008), an observation which has implications for those studies that are based on ad hoc teams to provide evidence on knowledge application aspects.

In addition, the existing literature has compared the quality of problem solving between traditional teams and virtual teams. The findings suggest that virtual teams end up with higher performance (Sharda et al., 1988), or at least not worse (Archer, 1990; Chidambaram \& Jones, 1993). However, virtual teams take longer to accomplish tasks (Archer, 1990; Sharda et al., 1988).

\section{DISCUSSION AND RECOMMENDATIONS FOR FUTURE RESEARCH QUESTIONS}

The analysis has identified a considerable diversity of factors that influence knowledge processes in virtual teams. We will now draw on this analysis to shed light on important aspects of virtual team knowledge processes that, to date, still remain under-explored and to provide research questions to guide future work in the area. The analysis is organized in accordance with the four knowledge processes with the core research questions summarized in Table 2.

Table 2 - Recommended Future Research Questions

\begin{tabular}{|l|l|}
\hline \multicolumn{1}{|c|}{ Knowledge process } & \multicolumn{1}{c|}{ Areas for Future Research } \\
\hline Knowledge Creation & $\begin{array}{l}\text { What are the influencing factors of effective on-job } \\
\text { learning/training within virtual teams? } \\
\text { What are the cumulative and opposing effects on knowledge } \\
\text { creation in virtual teams and how can these factors be balanced out } \\
\text { by management initiatives? }\end{array}$ \\
\hline Knowledge & How does the motivational disposition of knowledge receiver and \\
\hline
\end{tabular}




\begin{tabular}{|l|l|}
\hline Transferring & $\begin{array}{l}\text { sender impact on the knowledge sharing process within virtual } \\
\text { teams? }\end{array}$ \\
\hline $\begin{array}{l}\text { Knowledge } \\
\text { Storage/Retrieving }\end{array}$ & $\begin{array}{l}\text { Which skills and traits are required by a knowledge manager to } \\
\text { successfully facilitate knowledge storage in virtual teams? } \\
\text { Which factors influence the quality of a knowledge repository } \\
\text { developed in virtual teams? }\end{array}$ \\
\hline $\begin{array}{l}\text { Knowledge } \\
\text { Application }\end{array}$ & $\begin{array}{l}\text { How do the processes of knowledge creation, knowledge sharing, } \\
\text { and knowledge storage contribute to knowledge application? } \\
\text { How do the levels of IT use and other context components impact } \\
\text { on the levels of knowledge application within virtual teams? }\end{array}$ \\
\hline $\begin{array}{l}\text { Combination of the } \\
\text { Four KM Processes }\end{array}$ & $\begin{array}{l}\text { Whether and how do structural and process factors of virtual teams } \\
\text { differ in their effects on different knowledge processes? }\end{array}$ \\
\hline Multi-Level Research & $\begin{array}{l}\text { What implications do knowledge processes at the team level have } \\
\text { on individual and firm level performance? } \\
\text { How do new developments in communication technology and } \\
\text { collaboration practices impact on knowledge processes of virtual } \\
\text { teams? }\end{array}$ \\
\hline
\end{tabular}

\section{Questions on knowledge creation}

Early virtual team research has paid significant attention to knowledge creation as the final objective of team activities. Most of the studies examine knowledge creation as a team task (Alavi, 1994; Alavi et al., 2002; Ocker \& Yaverbaum, 1999; Qureshi \& Vogel, 2001). However, such a team task setting seldom happens to virtual teams in real organizations. Instead, virtual teams are formed to solve a practical problem by integrating team members' current knowledge, skills and ability (Powell et al., 2004). In most cases, knowledge creation is a by-product of teamwork. That is, teams themselves often become the "training grounds for the acquisition of new skills and knowledge areas" (Cianni \& Wnuck, 1977, p. 106). Consequently, to facilitate team members' on-job knowledge creation is of considerable importance as the knowledge is particularly relevant and context-specific, thus possessing high value for the team. Given the importance and prevalence of this mode of knowledge creation future studies should not only investigate knowledge creation per se, but to focus on the factors that facilitate on-job-learning 'as a by-product' of a task completion. 
Another important observation that emanated from the literature review refers to the diversity of factors that impact on the knowledge creation process within virtual teams. While some of these factors contribute to the knowledge creation process (e.g. collaboration know how) others inhibit the knowledge creation process (e.g. information systems requiring advanced cognitive processes). With research so far having largely focused on these factors in isolation virtual team managers cannot focus on individual factors but need to be able to consider the complex web of dependencies which are created by these diverse factors. To be able to provide further implications for practice future research should focus on identifying the cumulative or opposing effects of these diverse factors with particular attention to the proactive balancing of these effects to better support knowledge creation within virtual teams.

\section{Questions on knowledge transferring}

The existing literature emphasizes on knowledge transfer processes but has largely overlooked agents who send or receive knowledge that is transferred. Szulanski (1996) suggests that knowledge flows can be conceptualized as a function of five factors based on communication theory, including 1) perceived value of the source knowledge; 2) motivational disposition of the source; 3) existence and richness of transmission channels; 4) motivational disposition of the receiver; 5) the absorptive capacity of the receiver. Given the importance of communication technology for knowledge transfer in virtual teams research has largely looked at existence and richness of transmission channels (e.g., IT as a means of communication) and ways to recognize perceived value of the source knowledge (e.g., mutual understanding, transactive memory); hardly any attention has been paid to the other three elements (i.e., motivational disposition of receiver and sender, absorptive capacity of the receiver), which are all deemed essential in knowledge transfer (Govindarajan, 2000) and which should not be overlooked due to a focus on the technology artifact. Yuan (2011) 
showed how sympathy towards others impacts on knowledge sharing behavior. To better understand the knowledge transfer process among virtual team members requires a focused investigation of the motivational disposition of knowledge receiver and sender, as well as the role of the knowledge receiver's absorptive capacity.

\section{Questions on knowledge storage/retrieving}

The lack of contributions focusing on knowledge storage and retrieval processes in the virtual team context is of particular interest. A possible explanation is that the explicit knowledge storage and retrieval as defined by Alavi and Leidner (2001) does not represent a core process in virtual teams. As the majority of exchanges among team members are carried out in a codified format automatically (e.g. email), the need for additional explicit system-based knowledge storage and retrieval mechanisms could be limited. Notwithstanding the codified nature of exchanges, the virtual context creates a particularly interesting context for knowledge storage and retrieval processes which leads to additional investigations: the knowledge storage process is highly dependent on the trust, motivation and shared background of the participants (Huber, 2001) which creates considerable research opportunities in the virtual team context where the emergence of trust and shared background is limited (Gibson \& Gibbs, 2006). Consequently, the role of the knowledge manager is more encompassing in a virtual team context, as not only the capturing and availability of important knowledge needs to be ensured (Malhotra et al., 2001) but also an environment needs to be created that helps individuals to overcome the inherent difficulties of the virtual context. Knowledge manager have to focus on the development of a shared understanding, learning climate and coaching practices to provide the climate in which knowledge processes are taking place (Hong \& Vai, 2008). Given that the knowledge storage process is even more delicate in a virtual team scenario, the changing role of the knowledge manager is of interest 
to determine the particular skills and traits a knowledge manager requires to successfully facilitate the important knowledge storage process in virtual teams.

A related matter for the virtual team context is the concern over content quality in a knowledge repository. It is often reported that codified knowledge in knowledge repositories is unlikely to be appropriately referenced for later search and retrieval (Majchrzak, Rice, King, et al., 2000). One explanation might be that knowledge is highly contextual and cannot be understood properly without capturing its local context. As virtual teams are often set up as temporary arrangements encompassing members with different degree of affiliation, the development of shared and local context creates an even greater challenge. Hence, future research is advised to pay additional attention to the factors that influence the quality of knowledge repository developed in virtual teams.

\section{Questions on knowledge application}

Knowledge application is arguably one of the major goals for which teams are formed (Grant, 1996). Knowledge application is the end while the other three KM processes are means to achieve this end. It seems that there must be close relationships between knowledge application process and the other three KM processes. However, in the current literature only few studies explicitly integrate knowledge application and knowledge transfer processes (e.g. Haas, 2006; Majchrzak, Rice, King, et al., 2000; Malhotra et al., 2001), or compare the performance complications of multiple knowledge processes in the same study (Haas, 2006; Paul, 2006). Future research should explore the extent to which knowledge application is related to the other three knowledge processes.

In a virtual team context the knowledge application process has received less attention and the few existing studies compare knowledge application between virtual teams and traditional teams by focusing on the level of IT use (Archer, 1990; Chidambaram \& Jones, 1993). 
However, as outlined above, while technology is an important determinant of the virtual team context and an important contributor of knowledge application, there are several other aspects that create the particular and often idiosyncratic context of virtual teams. A crude comparison between virtual teams and traditional teams does not provide the appropriate perspective for determining the idiosyncratic conditions of a virtual team. Consequently, future research should start focusing on the diversity of virtual teams, hereby comparing the effect of various levels of IT use (e.g., basic IT such as email vs. advanced collaboration tools) but also focusing on other context variables.

\section{Questions on a holistic approach to knowledge processes in virtual settings}

By examining input factors and process factors identified in the extant literature, it appears that range of factors remain applicable for multiple knowledge processes. For instance, structural factors of virtual teams (e.g., degree of virtualness, degree and types of information technologies, leadership behaviors) are identified as important factors to multiple knowledge processes. Similarly, factors such as transactive memory, shared understanding, and collective mind appear to be equally important to multiple knowledge processes. This leads us to a reasonable speculation that these factors may in fact influence the effectiveness of all knowledge processes. While it is worthwhile to test how these factors play a role in the knowledge processes that have been covered, a more pertinent question remains: whether and how do these structural and process factors of virtual teams differ in their effects on different knowledge processes?

\section{Opportunities for multi-level research}

The organizational learning literature has pointed out that learning is a multi-level process composed of diverse knowledge processes, such as individual learning through intuition and interpretation and collective learning through shared interpretation and joint knowledge 
integration (Crossan et al., 1999). Kang (2010) elaborated on the dependency between individual and group-based knowledge transfer processes in non-virtual environments. Virtual team research has also begun to examine knowledge processes in a more holistic, less separated fashion. For instance, through an inductive study of multiple dispersed teams, Sole and Edmondson (2002) identified that bridging knowledge gaps in virtual teams requires both individual knowledge creation and collective knowledge integration. Griffith et al (1999) suggest that, to leverage potential knowledge held by team members, individuals must establish absorptive capacity and communities of practice, and the entire team must develop synergy and transactive memory to integrate the existing knowledge and point members directly to the critical knowledge resources. The multi-level process of knowledge creation has particular implications for virtual teams as team members face more challenges in creating synergies and shared interpretation. To which extent team-level and individual-level knowledge creation is synchronized and how these processes contribute to organizational benefits has been theoretically described but little empirical work has been conducted for the virtual team context. Hence, future research should investigate how knowledge processes at the team level have individual and firm level performance implications.

Overall, most studies reviewed here understand virtual teams as a stable and discrete entity (e.g. Robert et al., 2008). However, recent developments in virtual collaboration and work practice (e.g. web 2.0, open source) suggest that the notion of the virtual team will need to be revised as memberships in these teams are often highly transient. Ratcheva (2009) has started to extend the notion of the virtual team by highlighting the diverse forms of memberships and team affiliations but more work is required to explore the effects these transient arrangements have on the knowledge processes within virtual teams. The emergent technologies not only blur the virtual team boundaries but are likely to have implications for the virtual team's diverse knowledge processes. Research so far has focused on email and decision support 
systems (Alavi et al., 2002) to determine the technology impact on knowledge creation in virtual teams. However, today's wiki technology and its collaborative editing feature, for example, provide completely new knowledge creation opportunities (Wagner \& Schroeder, 2010). To remain current, virtual team research needs to consider the implications of these new technological affordances and investigate how the changing boundaries and practices impact on the knowledge processes in virtual teams.

\section{LIMITATIONS AND CONCLUSION}

In this paper, our aim was to investigate the current state of research on knowledge processes in virtual teams and to identify the factors that influence the effectiveness of these knowledge processes. Our literature search has identified 33 relevant papers that were systematically analyzed to highlight their contributions to research and to establish a comprehensive overview of the existing literature on this topic. By drawing on an established framework (Alavi \& Leidner, 2001, knowledge processes, input/process/output) we were able to categorize the influencing factors but also integrate the diverse research findings and contributions of the diverse studies identified. We hope that our categorization will guide future studies on knowledge processes in virtual teams and will help to position future research. Our study has further identified and presented a range of gaps in the current state of research. The research gaps were identified based on the theoretical insights provided by the literature and we hope that the identification of the research gaps will help to guide future virtual team research.

In addition to providing a comprehensive review of the literature and identifying research gaps, our study contributes to illustrating the ongoing relevance of virtual team research for management practice. The last decade of virtual team research has contributed a large number of theoretical insights often in the form of rigorously established relationships between 
individual aspects of the virtual team context. However, management practice often needs to not just consider individual effects but the range of influences as the basis for careful decision making. Hence, especially our call for research on the cumulative and opposing effects that different factors have on the knowledge processes are crucial for allowing managers to use the existing research base. Only by carefully considering the range of effects can the desired managerial impact be ensured.

Notwithstanding the theoretical and practical implications our study has several limitations. First, by seeking to provide comprehensiveness our review could only provide limited insights from the diverse literature sources analyzed to understand the individual knowledge processes. Second, every framework and model highlights particular aspects over others. We followed Alavi and Leidner's (2001) framework to contribute to the cumulative tradition of knowledge process research and provide the opportunity to integrate our findings with the extent IS research. An inductive method for analyzing the literature on knowledge processes in virtual teams would constitute a very valuable alternative approach that would likely create additional insights and would allow to compare and corroborate our current findings. Third, the literature base could be expanded to include virtual team research articles beyond the business discipline. With the qualitative analysis being our main direction and the display of the areas of research our main focus, our method and corpus is not suitable for a quantitative analysis. Fourth, as our study synthesizes investigations that adopt different methodologies, theories and variables the properties of the identified relationships are not directly comparable and the development of an integrative model is more difficult than for research domains where studies adopt a coherent theoretical position (e.g. King, 2006). By categorizing the core factors impacting on particular knowledge processes, our study aids future research that seeks to quantitatively explore individual relationships and consolidate 
equivocal findings. Our study provides the basis for these and further investigations on knowledge processes in virtual teams.

A substantial body of studies has been carried on virtual teams as well as on knowledge processes as both topics in its own right remain of considerable interest to research and practice. However, the paradox of virtual teams requires a focus on the intersection of these two research areas: virtual teams are largely established to join disparate knowledge resources while, at the same time, it is the virtualness of the teams that creates the barriers to knowledge processes. As we can observe a continuous increase in the virtualisation of work practices this particular research focus is likely to become of even greater relevance. We believe that our work has the potential to help to rapidly fill the gaps in our understanding of knowledge issues in virtual teams and help move forward research and practice in the field.

\section{REFERENCES}

Accenture. (2005 ). Mission Critical Workforce Performance: Accenture.

Ahuja, G. (2000). Collabroation Networks, Structural Holes and Innovation: A Longitudinal Study. Administrative Science Quarterly, 42(3), 425-455.

Alavi, M. (1994). Computer-mediated collaborative learning: An empirical evaluation. MIS Quarterly, 18(2), 159-175.

Alavi, M., \& Leidner, D. E. (2001). Review: Knowledge management and knowledge management systems: Conceptual foundations and research issues. MIS Quarterly, 25(1), 107-136.

Alavi, M., Marakas, G. M., \& Yoo, Y. (2002). A comparative study of distributed learning environments on learning outcomes. Information Systems Research, 13(4), 404-415.

Alavi, M., \& Tiwana, A. (2002). Knowledge Integration in Virtual Teams: The Potential Role of KMS. Journal of the American Society for Information Science and Technology, 53(12), 1029-1037.

Archer, N. P. (1990). A Comparison of computer conferences with Face-to-Face meetings for small group business decisions. Behavior \& Information Technology, 9(4), 307-317.

Argyris, C., \& Schon, D. (1978). Organizational Learning: A theory of action perspective. Reading MA: Addison-Wesley.

Assudani, R. H. (2009). Dispersed knowledge work - implications for knowledge intensive firms. Journal of Knowledge Management, 13(6), 521-532.

Baba, M. L., Gluesing, J., Ratner, H., \& Wagner, K. H. (2004). The contexts of knowing: natural history of a globally distributed team. Journal of Organizational Behavior, 25(5), 547-587.

Behrend, F. D., \& Erwee, R. (2009). Mapping knowledge flows in virtual teams with SNA. Journal of Knowledge Management, 13(4), 99-114.

Berger, P. L., \& Luckmann, T. (1967). The Social Construction of Knowledge--A Treatise in the Sociology of Knowledge. London: Allen Lane.

Bosch-Sijtsema, P. M., Ruohomaki, V., \& Vartiainen, M. (2009). Knowledge work productivity in distributed teams. Journal of Knowledge Management, 13(6), 533-546.

Boutellier, E. A. (1998). Management of dispersed product development teams: The role of information technology. R\&D Management, 28(1), 13-26. 
Capece, G., \& Costa, R. (2009). Measuring knowledge creation in virtual teams through the social network analysis. Knowledge Management Research \& Practice, 7, 329-338.

Chang, K. T. (2008). Psychological Contracts and Knowledge Exchange in Virtual Teams Paper presented at the International Conference on Information Systems, Paris.

Chidambaram, L., \& Jones, B. (1993). Impact of communication medium and computer support on group perceptions and performance: A comparison of face-to-face and dispersed meetings. MIS Quarterly, 17(4), 465-491.

Choi, S. Y., Lee, H., \& Yoo, Y. (2010). The impact of information technology and transactive memory systems on knowledge sharing, application, and team performance: a field study. MIS Quarterly, 34(4), 855870.

Cianni, M., \& Wnuck, D. (1977). Individual Growth and Team Enhancement: Moving toward a new model of career development. Academy of Management Executive, 11, 105-115.

Clark, H., \& Carlson, T. (1982). Speech acts and hearer's beliefs. In N. D. Smith (Ed.), Mutual Knowledge. New York: Academic Press.

Clear, T., \& Daniels, M. (2000). In Using Groupware For International Collaborative Learning. Paper presented at the American Society for Engineering Education/Institute of Electrical and Electronics Engineers Frontiers in Education Conference, Kansas, Missouri.

Cohen, S. G., \& Bailey, D. E. (1997). What makes teams work: Group effectiveness research from the shop floor to the executive suite. Journal of Management Information Systems, 23(3), 239-290.

Cornelius, C., \& Boos, M. (2003). Enhancing mutual understanding in synchronous computer-mediated communication by training: Trade-offs in judgmental tasks. Communication Research, 30(2), 147-177.

Cramton, C. D. (2001). The mutual knowledge problem and its consequences for dispersed collaboration. Organization Science, 12(3), 346-371.

Crossan, M. M., Lane, H. W., \& White, R. E. (1999). An organizational learning framework : from intuition to institution. Academy of Management review, 24(3), 522-537.

Davidow, W. H., \& Malone, M. S. (1992). The Virtual Corporation. California Business Review, 27(11), 34-39.

Dean, J. W., Sharfman, M. P. (1996). Does Decision Process Matter? A Study of Strategic Decision-Making Effectiveness. Academy of Management Journal, 39(2), 368-396.

Edmondson, A. (1999). Psychological Safety and Learning Behavior in Work Team. Administrative Science Quarterly, 44(2), 350-383.

Edmondson, A. (2002). The local and variegated nature of learning in organizations: A group-level perspective. Organization Science, 13(2), 128-146.

Gammelgaard, J. (2010). Knowledge retrieval through virtual communities of practice. Behaviour \& Information Technology, 29(4), 349-362.

Gibson, C. B., \& Gibbs, J. L. (2006). Unpacking the Concept of Virtuality: The Effects of Geographic Dispersion, Electronic Dependence, Dynamic Structure, and National Diversity on Team Innovation. Administrative Science Quarterly, 51(3), 451-495.

González-Pereira, B., Guerrero-Bote, V. P., \& Moya-Anegón, F. (2010). A new approach to the metric of journals' scientific prestige: The SJR indicator. Journal of Informetrics, 4(3), 379-391.

Govindarajan, A. K. G. (2000). Knowledge Flows within Multinational Corporations. Strategic Management Journal, 21(4), 473-496.

Grant, R. M. (1996). Toward a Knowledge-based Theory of the Firm. Strategic Management Journal, 17(Winter Special Issue), 109-122.

Greeno, J. G. (1974). Processes of learning and comprehension. In L. W. Greg (Ed.), Knowledge and cognition. Hillsdale, NJ: Lawrence Erlbaum Associates.

Griffith, T. L. (1999). Technology Features as Triggers for Sensemaking. Academy of Management Review, 24(3), 472-488.

Griffith, T. L., \& Neale, M. A. (2001). Information processing in traditional, hybrid and virtual teams: From nascent knowledge to transactive memory. Research in Organizational Behavior, 23, 379-421.

Griffith, T. L., Sawyer, J. E., \& Neale, M. A. (2003). Virtualness and knowledge in teams: Managing the love triangle of organizations, individuals, and information technology. MIS Quarterly, 27(2), 265-287.

Guo, Z., \& Sheffield, J. (2008). A paradigmatic and methodological examination of knowledge management research: 2000 to 2004. Decision Support Systems, 44, 673- 688.

Gurvitch, G., Thompson, M. A., \& Thompson, K. A. (1971). The social frameworks of knowledge: Blackwell.

Haas, M. R. (2006). Acquiring and applying knowledge in transnational teams: The roles of cosmopolitans and locals. Organization Science, 17(3), 367-384.

Hackman, J. R. (1992). Group influences on individuals in organizations. In M. Dunnette \& L. M. Hough (Eds.), Handbook of industrial and organizational psychology. Palo Alto, CA: Consulting Psychologists Press Inc. 
Hertel, G., Geister, S., \& Konradt, U. (2005). Managing virtual teams: A review of current empirical research. Human Resource Management Review, 15, 69-95.

Holzner, B., \& Marx, J. H. (1979). Knowledge application: The knowledge system in society. Boston: Allyn and Bacon.

Hong, J. F. L., \& Vai, S. (2008). Knowledge-sharing in cross-functional virtual teams. Journal of General Management, 34(2), 21-37.

Huber, G. (2001). Transfer of knowledge in knowledge management systems: unexplored issues and suggested studies. European Journal of Information Systems, 10, 72-79.

Intel Corporation. (2004). eWorkforce: Enabling the global vision: Intel Corporation.

Kang, M. (2010). A Multilevel View on Interpersonal Knowledge Transfer Minhyung Kang. Journal of American Society for Information Science and Technology, 61(3), 483-494.

Keen, P. G. W. (1980). MIS Research: Reference Disciplines and a Cumulative Tradition. Paper presented at the 1st International Conference on Information Systems, Philadelphia.

Kim, Y., \& Jarvenpaa, S. L. (2008). Formal Boundary Spanning and Informal Boundary Spanning in CrossBorder Knowledge Sharing: A Case Study. Paper presented at the Hawaii International Conference on System Sciences.

King, W. R. (2006). A meta-analysis of the technology acceptance model. Information \& Management, 43(6), 740-755.

Kolb, D. A., \& Fry, R. (1975). Toward an applied theory of experiential learning. In C. Cooper (Ed.), Theories of Group Process. London: John Wiley.

Krauss, R., \& Fussel, S. (1990). Mutual Knowlege and communicative effectiveness. In R. K. C. E. J. Galegher (Ed.), Intellectual Teamwork: Social and Technological Foundations of Cooperative Work. Hillsdale: Lawrence Erlbaum.

Kruempel, K. (2000). Making the right (interactive) moves for knowledge-producing tasks in computermediated groups. IEEE Transactions on Professional Communication, 43(2), 185 - 195.

Kwok, R. C. W., Jian, M., \& Vogel, D. (2002). Effects of group support systems and content facilitation on knowledge acquisition. Journal of Management Information Systems, 19(3), 185-229.

Langfred, C. (1998). Is group cohesiveness a double-edged sword? An investigation of the effects of cohesiveness on performance. Small Group Research, 29(1), 124-143.

Lee, H., \& Choi, B. (2003). Knowledge management enablers, processes, and organizational performance: an integrative view and empirical examination. Journal of Management Information Systems, 20(1), 179228.

Leonard, D., \& Sensiper, S. (1998). The role of tacit knowledge in group innovation. California Management Review, 40(3), 112-132.

Maier, R. (2007). Knowledge Management Systems: Information and Communication Technologies for Knowledge Management. Berlin: Springer.

Majchrzak, A., Malhotra, A., \& John, R. (2005). Perceived individual collaboration know-how development through information technology-enabled contextualization: Evidence from distributed teams. Information Systems Research, 16(1), 9-27.

Majchrzak, A., Rice, R. E., King, N., Malhotra, A., \& Ba, S. (2000). Computer-mediated inter-organizational knowledge-sharing: Insights from a virtual team innovating using a collaborative tool. Information Resources Management Journal, 13(1), 44-53.

Majchrzak, A., Rice, R. E., Malhotra, A., King, N., \& Ba, S. (2000). Technology adaptation: The case of a computer-supported inter-organizational virtual team. MIS Quarterly, 24(4), 569-600.

Malhotra, A., \& Majchrzak, A. (2004). Enabling Knowledge Creation In Far-Flung Teams: Best Practices For IT Support And Knowledge Sharing. Journal of Knowledge Management, 8(4), 75-88.

Malhotra, A., Majchrzak, A., Carman, R., \& Lott, V. (2001). Radical innovation without collocation: A case study at Boeing-Rocketdyne. MIS Quarterly, 25(2), 229-249.

Markus, M. L., Manville, B., \& Agres, C. E. (2000). What Makes a Virtual Organization Work? MIT Sloan Management Review, 42(1), 13-26.

Martins, L., Gilson, L., \& Maynard, M. (2004). Virtual teams: What do we know and where do we go from here? Journal of Management, 30(6), 805-835.

Miles, R. E., \& Snow, C. C. (1992). Causes of Failure in Network Organizations. California Management Review, 34(4), 53-72.

Ocker, R. J., \& Yaverbaum, G. J. (1999). Asynchronous Computer-mediated Communication versus Face-toface Collaboration: Results on Student Learning, Quality and Satisfaction. Group Decision and Negotiation, 8(5), 427-440.

Olivera, F., \& Straus, S. G. (2004). Group-to-individual transfer of learning: Cognitive and social factors. Small Group Research, 35(4), 440-465. 
Palanisamy, R. (2007). Organizational culture and knowledge management in ERP implementation: An empirical study. Journal of Computer Information Systems, 48(2), 100-120.

Paul, D. L. (2006). Collaborative activities in virtual settings: A knowledge management perspective of telemedicine. Journal of Management Information Systems, 22(4), 143-176.

Peachy, T., Hall, D., \& Cegielski, C. (2005). Knowledge Management and the Leading Information Systems Journals: An Analysis of Trends and Gaps in Published Research. International Journal of Knowledge Management, 1(3), 55-69.

Penrose, E. (1959). The Theory of the Growth of the Firm. Oxford: Basil Blackwell.

Pinsonneault, A., \& Caya, O. (2005). Virtual teams: What we know, what we don't know. International Journal of E-Collaboration, 1(3), 1-16.

Powell, A., Piccoli, G., \& Ives, B. (2004). Virtual teams: A review of the current literature and directions for future research. The DATABASE for Advances in Information Systems, 35(1), 6-36.

Qureshi, S., \& Vogel, D. (2001). Adaptiveness in Virtual Teams: Organisational Challenges and Research Directions. .Group Decision and Negotiation, 10(1), 27-46.

Ratcheva, V. (2009). Integrating diverse knowledge through boundary spanning processes - The case of multidisciplinary project teams. International Journal of Project Management 27, 206-215.

Robert, L. P., Dennis, A. R., \& Ahuja, M. K. (2008). Social capital and knowledge integration in digitally enabled teams. Information Systems Research, 19(3), 314-334.

Robey, D., Khoo, H. M., \& Powers, C. (2000). Situated learning in cross-functional virtual teams. IEEE Transaction on Professional Communication, 43(1), 51-66.

Rubenstein-Montano, B. (2001). A systems thinking framework for knowledge management. Decision Support Systems, 31(1), 5-16.

Saunders, C. S. (2000). Virtual Teams: Piecing Together the Puzzle. In B. Zmud (Ed.), Framing the domain of IT management: Projecting the future through the past. Cincinnati: Pinnaflex.

Senge, P. M. (1990). The fifth discipline: The art and practice of the learning organization. New York, NY: Doubleday.

Sharda, R., Barr, S. H., \& McDonnell, J. C. (1988). Decision support system effectiveness a review and an empirical study. Management Science, 34(2), 139-159.

Siebdrat, F., Hoegl, M., \& Ernst, H. (2009). How to manage virtual teams. MIT Sloan Management Review, 50(4), 63-68.

Sole, D., \& Applegate, L. (2000). Knowledge Sharing Practices and Technology Use Norms in Dispersed Development Teams. Paper presented at the International Conference on Information Systems.

Sole, D., \& Edmondson, A. (2002). Situated knowledge and learning in dispersed teams. British Journal of Management, 13(2), 17-34.

Staples, D. S., \& Webster, J. (2008). Exploring the effects of trust, task interdependence and virtualness on knowledge sharing in teams. Information Systems Journal, 18, 617-640.

Szulanski. (1996). Exploring internal stickiness: Impediments to the transfer of best practice within the firm. Strategic Management Journal, 17, 27-43.

Townsend, A. M., De Marie, S. M., \& Hendrickson, A. R. (1998). Virtual teams: Technology and the workplace of the future. Academy of Management Executive, 12(3), 17-29.

Vaccaro, A., Veloso, F., \& Brusoni, S. (2009). The impact of virtual technologies on knowledge-based processes: An empirical study. Research Policy 38(8), 1278-1287.

Vogel, D., Genuchten, V., Lou, M. D., Verveen, S., Eekout, V., \& Adams, A. (2001). Exploratory research on the role of national and professional cultures in a distributed learning project. IEEE Transactions on Professional Communication, 44(2), 114-125.

Wagner, C., \& Schroeder, A. (2010). Capabilities and roles of enterprise wikis in organizational communication. Technical Communication, 57(1), 68-89.

Walsh, J. P. (1995). Managerial and organizational cognition: Notes from a trip down memory lane. Organization Science, 6(3), 280-321.

Workman, M. (2007). The proximal-virtual team continuum: A study of performance. Journal of the American Society for Information Science and Technology, 58(6), 794-801.

Wu, C.-H., Kao, S.-C., \& Shih, L.-H. (2010). Assessing the suitability of process and information technology in supporting tacit knowledge transfer. Behaviour \& Information Technology, 29(5), 513-525.

Yoo, Y. (2001). Developments of transactive memory systems and collective mind in virtual teams. International Journal of Organizational Analysis, 9(2), 178-208.

Yuan, Y. C. (2011). The Interplay Between Interpersonal and Electronic Resources in Knowledge Seeking Among Co-Located and Distributed Employees. Journal of American Society for Information Science and Technology, 62(3), 535-549. 
Appendix I - Articles Included in the Review

\begin{tabular}{|c|c|c|c|c|c|c|c|c|}
\hline Authors & Topic & KM process & Technology & Task & Theory & Method & Subjects & Time Frame \\
\hline Alavi, M. 1994. & $\begin{array}{l}\text { Cognitive learning } \\
\text { Cognitive load of } \\
\text { learning process }\end{array}$ & Knowledge creation & Email vs. GDSS & $\begin{array}{l}\text { Develop thorough } \\
\text { understanding of a } \\
\text { customer-oriented } \\
\text { program } \\
\end{array}$ & $\begin{array}{l}\text { Social learning } \\
\text { theory }\end{array}$ & $\begin{array}{l}\text { Experiment - } \\
\text { control variable } \\
\text { different level of } \\
\text { GDSS } \\
\end{array}$ & $\begin{array}{l}450-\text { member } \\
\text { groups of } \\
\text { EMBAs }\end{array}$ & $\begin{array}{l}\text { 10-week } \\
\text { distance } \\
\text { learning }\end{array}$ \\
\hline $\begin{array}{l}\text { Alavi, M., G.M. } \\
\text { Marakas, Y. Yoo. } \\
2002\end{array}$ & $\begin{array}{l}\text { TML, including IT- } \\
\text { enabled } \\
\text { collaborative } \\
\text { learning } \\
\end{array}$ & Knowledge creation & $\mathrm{N} / \mathrm{A}$ & $\mathrm{N} / \mathrm{A}$ & TML theories & N/A & $\mathrm{N} / \mathrm{A}$ & $\mathrm{N} / \mathrm{A}$ \\
\hline $\begin{array}{l}\text { Alavi, M., Tiwana } \\
\text { A. } 2002 \text {. }\end{array}$ & $\begin{array}{l}\text { Challenges to } \\
\text { Knowledge } \\
\text { application by VTs }\end{array}$ & Knowledge application & $\mathrm{N} / \mathrm{A}$ & $\mathrm{N} / \mathrm{A}$ & $\begin{array}{l}\text { Communication } \\
\text { theory }\end{array}$ & N/A & $\mathrm{N} / \mathrm{A}$ & $\mathrm{N} / \mathrm{A}$ \\
\hline Archer, N.P. 1990. & $\begin{array}{l}\text { Knowledge } \\
\text { generation: } \\
\text { Decision quality, \# } \\
\text { alternatives } \\
\end{array}$ & Knowledge application & computer conferencing & Decision making & AST & Experiment & $\begin{array}{l}\text { 4-5 member } \\
\text { teams, students }\end{array}$ & 8 week \\
\hline $\begin{array}{l}\text { Baba, M.L., } \\
\text { Gluesing, J., } \\
\text { Ratner, H., } \\
\text { Wagner, K.H. } \\
2004\end{array}$ & $\begin{array}{l}\text { Cognition } \\
\text { convergence }\end{array}$ & Knowledge transfer & $\begin{array}{l}\text { Videoconferencing } \\
\text { Electronic meeting } \\
\text { system } \\
\text { Knowledge repository }\end{array}$ & $\begin{array}{l}\text { Customer } \\
\text { relationship } \\
\text { management }\end{array}$ & Shared cognition & Ethnography & $\begin{array}{l}1 \text { global virtual } \\
\text { team }\end{array}$ & 14 months \\
\hline $\begin{array}{l}\text { Behrend, D., } \\
\text { Erwee, R. } 2009\end{array}$ & Social network & Knowledge transfer & $\mathrm{N} / \mathrm{A}$ & $\mathrm{N} / \mathrm{A}$ & $\begin{array}{l}\text { Social network } \\
\text { theory }\end{array}$ & $\begin{array}{l}\text { Case study, survey } \\
\text { method }\end{array}$ & 6 virtual teams & $\mathrm{N} / \mathrm{A}$ \\
\hline $\begin{array}{l}\text { Boutellier, E.A. } \\
1998\end{array}$ & $\begin{array}{l}\mathrm{R} \& \mathrm{D} \text { as knowledge } \\
\text { production }\end{array}$ & Knowledge application & Various technologies & $\begin{array}{l}\text { Commercial } \\
\text { software } \\
\text { development } \\
\end{array}$ & $\mathrm{N} / \mathrm{A}$ & Case study & $\mathrm{N} / \mathrm{A}$ & $\mathrm{N} / \mathrm{A}$ \\
\hline $\begin{array}{l}\text { Capece, G. Costa, } \\
\text { R. } 2009\end{array}$ & $\begin{array}{l}\text { Team structural } \\
\text { configuration }\end{array}$ & Knowledge creation & Various technologies & $\begin{array}{l}\text { Website } \\
\text { development }\end{array}$ & $\begin{array}{l}\text { Social network } \\
\text { theory }\end{array}$ & $\begin{array}{l}\text { Social Network } \\
\text { Analysis }\end{array}$ & $\begin{array}{l}46 \text {-member } \\
\text { teams }\end{array}$ & 7 weeks \\
\hline Chang K.T. 2008 & $\begin{array}{l}\text { Influence of } \\
\text { psychological } \\
\text { contracts on } \\
\text { knowledge sharing }\end{array}$ & knowledge transfer & $\mathrm{N} / \mathrm{A}$ & $\begin{array}{l}36 \text { Software } \\
\text { development teams } \\
\text { which are part of } \\
\text { one R\&D unit }\end{array}$ & $\begin{array}{l}\text { Psychological } \\
\text { contract theory }\end{array}$ & Survey & 252 members & $\mathrm{N} / \mathrm{A}$ \\
\hline
\end{tabular}




\begin{tabular}{|c|c|c|c|c|c|c|c|c|}
\hline Cramton, C. 2001. & $\begin{array}{l}\text { Structural } \\
\text { antecedents, and } \\
\text { consequences of } \\
\text { Mutual } \\
\text { knowledge/mutual } \\
\text { understanding }\end{array}$ & Knowledge transfer & $\begin{array}{l}\text { Email, other } \\
\text { communication tools }\end{array}$ & $\begin{array}{l}\text { Developing a } \\
\text { business plan and } \\
\text { prepare for } \\
\text { presentation }\end{array}$ & $\begin{array}{l}\text { Communication lit, } \\
\text { Attribution theory, } \\
\text { the concept of } \\
\text { cognitive load and } \\
\text { feedback dynamics }\end{array}$ & $\begin{array}{l}\text { Analysis of } 1649 \\
\text { emails } \\
\text { printouts of their } \\
\text { online chats } \\
\text { tem logs of their use } \\
\text { of communication } \\
\text { tool } \\
26 \text { analysis papers } \\
\text { grades }\end{array}$ & $\begin{array}{l}136 \text {-member } \\
\text { teams, all } \\
\text { graduate } \\
\text { students in the } \\
\text { U.S. }\end{array}$ & 7 weeks \\
\hline $\begin{array}{l}\text { Gibson, C.B., } \\
\text { Gibbs, J.L. } 2006\end{array}$ & $\begin{array}{l}\text { Team structure and } \\
\text { innovation }\end{array}$ & Knowledge application & $\begin{array}{l}\text { Email, } \\
\text { Teleconference } \\
\text { Text exchange }\end{array}$ & Aerospace design & $\begin{array}{l}\text { Psychological } \\
\text { safety }\end{array}$ & $\begin{array}{l}\text { Case study + } \\
\text { survey }\end{array}$ & $\begin{array}{l}14 \text { teams }+56 \\
\text { teams }\end{array}$ & $\mathrm{N} / \mathrm{A}$ \\
\hline $\begin{array}{l}\text { Griffith, T.L., and } \\
\text { M.A. Neale. } 2001 .\end{array}$ & $\begin{array}{l}\text { Transactive } \\
\text { memory }\end{array}$ & Knowledge transfer & ICT & $\mathrm{N} / \mathrm{A}$ & $\begin{array}{l}\text { Theory of } \\
\text { transactive memory }\end{array}$ & N/A, Theory paper & $\mathrm{N} / \mathrm{A}$ & $\mathrm{N} / \mathrm{A}$ \\
\hline $\begin{array}{l}\text { Griffith, T.L., } \\
\text { Sawyer, J.E., } \\
\text { Neale, M.A.. } 2003 .\end{array}$ & $\begin{array}{l}\text { Knowledge transfer } \\
\text { and knowledge } \\
\text { acquisition in more } \\
\text { or less virtual } \\
\text { teams }\end{array}$ & Knowledge transfer & $\begin{array}{l}\text { ICT, Collaborative } \\
\text { technology }\end{array}$ & $\mathrm{N} / \mathrm{A}$ & $\begin{array}{l}\text { Communication } \\
\text { theory }\end{array}$ & $\mathrm{N} / \mathrm{A}$ & $\mathrm{N} / \mathrm{A}$ & $\mathrm{N} / \mathrm{A}$ \\
\hline Haas, M.R. 2006 & $\begin{array}{l}\text { Cosmopolitan } \\
\text { versus local } \\
\text { membership, } \\
\text { knowledge, and } \\
\text { performance } \\
\end{array}$ & $\begin{array}{l}\text { Knowledge creation } \\
\text { lapplication }\end{array}$ & $\begin{array}{l}\text { Email, teleconferencing, } \\
\text { telephone }\end{array}$ & $\begin{array}{l}\text { International } \\
\text { development }\end{array}$ & $\begin{array}{l}\text { International } \\
\text { management }\end{array}$ & Survey & $\begin{array}{l}96 \text { international } \\
\text { virtual teams }\end{array}$ & $\mathrm{N} / \mathrm{A}$ \\
\hline $\begin{array}{l}\text { Kim Y., Jarvenpaa } \\
\text { S. L. } 2008\end{array}$ & $\begin{array}{l}\text { Effect of boundary } \\
\text { spanning } \\
\text { mechanism on } \\
\text { knowledge transfer }\end{array}$ & Knowledge transfer & $\begin{array}{l}\text { Diverse information } \\
\text { technology }\end{array}$ & R\&D projects & $\mathrm{N} / \mathrm{A}$ & $\begin{array}{l}\text { longitudinal case } \\
\text { study }\end{array}$ & $\begin{array}{l}30 \text { individuals } \\
\text { within } 8 \\
\text { manufact.g } \\
\text { groups and } 2 \\
\text { admin. groups } \\
\end{array}$ & One year \\
\hline Krumpel, K. 2000 & $\begin{array}{l}\text { Group knowledge } \\
\text { generation, the } \\
\text { effect of leader }\end{array}$ & Knowledge application & Email & $\begin{array}{l}\text { Technology } \\
\text { standardization }\end{array}$ & $\begin{array}{l}\text { Structuration theory } \\
\text { CMC literature }\end{array}$ & Case study & $\begin{array}{l}\text { working group, } \\
51 \text { members }\end{array}$ & Ongoing \\
\hline $\begin{array}{l}\text { Majchrzak, A., } \\
\text { Rice, R.E., } \\
\text { Malhotra A., King } \\
\text { N., Ba S.. 2000b. }\end{array}$ & $\begin{array}{l}\text { Knowledge sharing, } \\
\text { innovative decision } \\
\text { making }\end{array}$ & $\begin{array}{l}\text { Knowledge transfer } \\
\text { Knowledge application }\end{array}$ & Collaborative technology & $\begin{array}{l}\text { Creating a highly } \\
\text { innovative product }\end{array}$ & AST & $\begin{array}{l}\text { Case study - } \\
\text { weekly virtual } \\
\text { meetings, electronic } \\
\text { log files, interviews } \\
\text { and weekly } \\
\text { questionnaires }\end{array}$ & $\begin{array}{l}18 \text {-member } \\
\text { team }\end{array}$ & $\begin{array}{l}10 \text { months } \\
\text { (15\% time } \\
\text { commitment) }\end{array}$ \\
\hline
\end{tabular}




\begin{tabular}{|c|c|c|c|c|c|c|c|c|}
\hline $\begin{array}{l}\text { Majchrzak, A., } \\
\text { Rice, R.E., } \\
\text { Malhotra A., King } \\
\text { N., Ba S... 2000a. }\end{array}$ & $\begin{array}{l}\text { Knowledge } \\
\text { sharing/commonalit } \\
\text { y }\end{array}$ & Knowledge transfer & Collaborative technology & $\begin{array}{l}\text { Creating a highly } \\
\text { innovative product }\end{array}$ & $\begin{array}{l}\text { Media } \\
\text { richness,Social } \\
\text { presenceTask } \\
\text { circumflex } \\
\end{array}$ & $\begin{array}{l}\text { Multi-method } \\
\text { longitudinal } \\
\text { research study }\end{array}$ & $\begin{array}{l}1 \text { eight- member } \\
\text { team }\end{array}$ & $\begin{array}{l}10 \text { months } \\
\text { (15\% time } \\
\text { commitment) }\end{array}$ \\
\hline $\begin{array}{l}\text { Majchrzak, A. } \\
\text { Malhotra, A. } \\
\text { John, R. } 2005\end{array}$ & $\begin{array}{l}\text { IT support and } \\
\text { knowledge } \\
\text { acquisition }\end{array}$ & Knowledge creation & $\begin{array}{l}\text { Lotus Notes, } \\
\text { Groove, } \\
\text { Netmeeting, } \\
\text { E-Room }\end{array}$ & A variety of tasks & $\begin{array}{l}\text { Cognitive - } \\
\text { affective model of } \\
\text { communication }\end{array}$ & Survey & 54 teams & $\mathrm{N} / \mathrm{A}$ \\
\hline $\begin{array}{l}\text { Malhotra, A., } \\
\text { Majchrzak A., R. } \\
\text { Carman, and V. } \\
\text { Lott. } 2001 .\end{array}$ & $\begin{array}{l}\text { Knowledge sharing } \\
\text { within VTs facing } \\
\text { highly innovative } \\
\text { goals }\end{array}$ & $\begin{array}{l}\text { Knowledge transfer } \\
\text { Knowledge storage and } \\
\text { retrieval }\end{array}$ & Collaborative technology & $\begin{array}{l}\text { Highly innovation - } \\
\text { Product } \\
\text { development } \\
\text { problem }\end{array}$ & $\mathrm{N} / \mathrm{A}$ & Case study & $\begin{array}{l}1 \text { eight-member } \\
\text { team }\end{array}$ & $\begin{array}{l}10 \text { months } \\
\text { (15\% time } \\
\text { commitment) }\end{array}$ \\
\hline $\begin{array}{l}\text { Malhotra, A., } \\
\text { Majchrzak, A. } \\
2004\end{array}$ & $\begin{array}{l}\text { Leverage globally } \\
\text { dispersed } \\
\text { knowledge } \\
\text { resources }\end{array}$ & Knowledge application & $\begin{array}{l}\text { Multiple technologies, } \\
\text { such as email, } \\
\text { collaborative technology, } \\
\text { teleconferencing }\end{array}$ & $\begin{array}{l}\text { Creating a highly } \\
\text { innovative product }\end{array}$ & $\mathrm{N} / \mathrm{A}$ & Case study / survey & 55 virtual teams & $\mathrm{N} / \mathrm{A}$ \\
\hline $\begin{array}{l}\text { Ocker, R.J., and } \\
\text { G.J. Yaverbaum. } \\
1999\end{array}$ & $\begin{array}{l}\text { The effectiveness } \\
\text { of learning using } \\
\text { computer-mediated } \\
\text { technology }\end{array}$ & Knowledge creation & $\begin{array}{l}\text { Asynchronous computer } \\
\text { conferencing tech }\end{array}$ & $\begin{array}{l}\text { Business case } \\
\text { analysis }\end{array}$ & $\begin{array}{l}\text { Computer- } \\
\text { mediated } \\
\text { communication in } \\
\text { education } \\
\end{array}$ & $\begin{array}{l}\text { Repeated-measure } \\
\text { experiment }\end{array}$ & $\begin{array}{l}10 \text { groups of } 43 \\
\text { MBA students }\end{array}$ & two weeks \\
\hline Paul 2006 & $\begin{array}{l}\mathrm{KM} \text { processes in } \\
\text { virtual settings }\end{array}$ & Knowledge creation/ transfer & $\begin{array}{l}\text { Videoconference } \\
\text { Multimedia }\end{array}$ & $\begin{array}{l}\text { Teleradiology } \\
\text { Distance learning } \\
\text { teleconsultation }\end{array}$ & Grounded theory & Case study & 10 virtual teams & $\mathrm{N} / \mathrm{A}$ \\
\hline $\begin{array}{l}\text { Qureshi, S., and } \\
\text { D. Vogel.2001 }\end{array}$ & $\begin{array}{l}\text { Learning, } \\
\text { Adaptation(technol } \\
\text { ogy, work, social), } \\
\text { structure, } \\
\text { specialization, } \\
\text { coordination }\end{array}$ & Knowledge creation & $\mathrm{N} / \mathrm{A}$ & $\mathrm{N} / \mathrm{A}$ & Structuration theory & N/A & $\mathrm{N} / \mathrm{A}$ & $\mathrm{N} / \mathrm{A}$ \\
\hline Ratcheva V. 2009 & $\begin{array}{l}\text { Integration of } \\
\text { multidisciplinary } \\
\text { knowledge through } \\
\text { boundary spanning }\end{array}$ & Knowledge transfer & $\mathrm{N} / \mathrm{A}$ & $\begin{array}{l}\text { Development of } \\
\text { high tech } \\
\text { components }\end{array}$ & $\mathrm{N} / \mathrm{A}$ & $\begin{array}{l}\text { longitudinal multiple } \\
\text { case study }\end{array}$ & 5 project teams & 6 months \\
\hline $\begin{array}{l}\text { Robert, L.P., } \\
\text { Dennis A.R., } \\
\text { Ahuja, M.K., } 2008\end{array}$ & $\begin{array}{l}\text { The impact of } \\
\text { social capital on } \\
\text { knowledge } \\
\text { sharing/application } \\
\text { and decision quality }\end{array}$ & $\begin{array}{l}\text { Knowledge } \\
\text { transfer/application }\end{array}$ & $\begin{array}{l}\text { Online communication } \\
\text { environment within } \\
\text { course management } \\
\text { software }\end{array}$ & $\begin{array}{l}\text { University } \\
\text { admission of } \\
\text { students }\end{array}$ & Social capital & Experiment & 46 teams & $\begin{array}{l}2 \text { hours } \\
\text { experiment } \\
\text { after } 2 \text { months } \\
\text { of social capital } \\
\text { building }\end{array}$ \\
\hline $\begin{array}{l}\text { Robey, D., Khoo } \\
\text { H.M.,, Powers C.. } \\
2000\end{array}$ & Situated learning & Knowledge creation & Various technology & $\begin{array}{l}\text { On-going } \\
\text { customer-specific } \\
\text { tasks }\end{array}$ & $\begin{array}{l}\text { Theory of situated } \\
\text { learning }\end{array}$ & Qualitative interview & $\begin{array}{l}22 \text { workers and } \\
\text { managers in } \\
\text { three cross- } \\
\text { functional teams }\end{array}$ & $3+$ years \\
\hline
\end{tabular}




\begin{tabular}{|c|c|c|c|c|c|c|c|c|}
\hline $\begin{array}{l}\text { Sole, D., } \\
\text { Applegate. L, } \\
2000\end{array}$ & $\begin{array}{l}\text { Team knowledge } \\
\text { sharing; } \\
\text { Team effectiveness }\end{array}$ & Knowledge transfer & $\begin{array}{l}\text { Collaborative tech in a } \\
\text { broad sense }\end{array}$ & $\begin{array}{l}\text { Solution } \\
\text { development }\end{array}$ & Shared meaning & $\begin{array}{l}\text { Field-based study } \\
\text { Semi-structured } \\
\text { interviews, reviews } \\
\text { of company } \\
\text { documents, } \\
\text { observation and } \\
\text { participation in } \\
\text { project }\end{array}$ & $\begin{array}{l}\text { Two } \\
\text { development } \\
\text { teams in a } \\
\text { company }\end{array}$ & $\mathrm{N} / \mathrm{A}$ \\
\hline $\begin{array}{l}\text { Sole, D., } \\
\text { Edmondson, A.. } \\
2002 .\end{array}$ & $\begin{array}{l}\text { The effect of } \\
\text { situated knowledge } \\
\text { on team } \\
\text { performance }\end{array}$ & Knowledge creation & $\begin{array}{l}\text { Computer-mediated } \\
\text { technology }\end{array}$ & Problem solving & $\begin{array}{l}\text { Theory of situated } \\
\text { learning }\end{array}$ & $\begin{array}{l}\text { Qualitative field } \\
\text { study }\end{array}$ & $\begin{array}{l}\text { seven } \\
\text { development } \\
\text { projects, each } \\
\text { spanning } \\
\text { multiple sites }\end{array}$ & $\mathrm{N} / \mathrm{A}$ \\
\hline $\begin{array}{l}\text { Staples D.S., } \\
\text { Webster J., } 2008\end{array}$ & $\begin{array}{l}\text { Effects of } \\
\text { virtualness and } \\
\text { task } \\
\text { interdependence } \\
\text { on the relationship } \\
\text { between trust, } \\
\text { knowledge sharing } \\
\text { and team } \\
\text { effectiveness }\end{array}$ & Knowledge transfer & $\mathrm{N} / \mathrm{A}$ & $\mathrm{N} / \mathrm{A}$ & $\begin{array}{l}\text { Social Exchange } \\
\text { theory }\end{array}$ & Survey & 824 participants & $\mathrm{N} / \mathrm{A}$ \\
\hline $\begin{array}{l}\text { Vaccaro, A., } \\
\text { Veloso, F., } \\
\text { Brusoni, S., } 2009\end{array}$ & $\begin{array}{l}\text { Effects of ICT on } \\
\text { knowledge creation } \\
\text { processes }\end{array}$ & Knowledge creation & $\begin{array}{l}\text { Different ICT tools, CAD, } \\
\text { workflow, databases }\end{array}$ & $\begin{array}{l}\text { R\&D projects in the } \\
\text { automotive sector. }\end{array}$ & $\begin{array}{l}\text { Model of } \\
\text { knowledge creation } \\
\text { (SECl) }\end{array}$ & Case research & $\begin{array}{l}\text { Two } \\
\text { engineering } \\
\text { development } \\
\text { teams } \\
\end{array}$ & 3 weeks \\
\hline $\begin{array}{l}\text { Vogel, D.R., } \\
\text { Davison, R.M. } \\
\text { Shroff, R.H., } 2001\end{array}$ & $\begin{array}{l}\text { Issues concerning } \\
\text { virtual team } \\
\text { learning }\end{array}$ & knowledge creation & $\begin{array}{l}\text { Group Systems } \\
\text { eRoom }\end{array}$ & $\begin{array}{l}\text { Managing software } \\
\text { projects } \\
\text { Identify the impact } \\
\text { of software defects } \\
\end{array}$ & $\begin{array}{l}\text { Cultural sensitive } \\
\text { theory of } \\
\text { sociocultural } \\
\text { learning; GSS }\end{array}$ & Case study & 7 virtual teams & Four weeks \\
\hline Yoo, Y., 2001. & $\begin{array}{l}\text { The effects of } \\
\text { transactive memory } \\
\text { and collective mind } \\
\text { on team } \\
\text { performance }\end{array}$ & Knowledge transfer & $\begin{array}{l}\text { Text-based computer } \\
\text { mediated- } \\
\text { communication } \\
\text { Web-based interfaces }\end{array}$ & $\begin{array}{l}\text { Business } \\
\text { simulation }\end{array}$ & $\begin{array}{l}\text { Social-cognitive } \\
\text { literature }\end{array}$ & $\begin{array}{l}\text { Longitudinal } \\
\text { surveys }\end{array}$ & $\begin{array}{l}38 \text { virtual teams } \\
\text { of graduate } \\
\text { students }\end{array}$ & Eight weeks \\
\hline
\end{tabular}

